\title{
The Promise of Things to Come: Anticipatory Warrants in Texas
}

\author{
By Gerald S. Reamey ${ }^{1}$ \\ We can never know about the days to come \\ But we think about them anyway .... Anticipation, anticipation \\ Is making me late \\ Is keeping me waiting ${ }^{2}$
}

Law enforcement involves a lot of speculation. Pieces of evidence sometimes come bundled neatly with no loose ends. More often, they emerge piecemeal over time, forming a clear picture only when joined together. As the whole begins to emerge from the parts, the temptation - and perhaps the need - to reach tentative conclusions grows. Premature conclusions based more on speculation than evidence are dangerous, and may result in wrongful arrests, prosecutions, and convictions. Waiting for conclusive evidence before taking action, on the other hand, carries its own potential costs. Delay risks the safety of the public and the frustration of justice. Adding to the investigator's dilemma is concern that vital, probative evidence may be excluded if it is seized improperly.

Judicial preapproval of searches and arrests is the principal constitutional mechanism for objectively evaluating the work of officers "engaged in the often competitive enterprise of ferreting out crime."3 Once considered a "requirement" of the Fourth Amendment, courts now

\footnotetext{
${ }^{1}$ Gerald S. Reamey is Professor of Law and Co-Director of International Legal Programs at St. Mary's University School of Law. Interest in this topic was sparked by an invitation from Ryan Kellus Turner, General Counsel for the Texas Municipal Courts Education Center, to prepare and present a class for municipal court judges on anticipatory warrants. Without his prompting, this article would not have been written. Helpful conversations with other presenters on this topic, Professor Charles Bubany of Texas Tech University Law School and Tom Bridges, greatly aided understanding of the implications of this procedure in Texas. The author also is grateful for the very capable research assistance of Amber Holmes in the preparation of this article.

${ }^{2}$ Carly Simon, Anticipation, 1971.

${ }^{3}$ Johnson v. United States, 333 U.S. 10 (1948).
} 
"prefer" warrants, but in terms that suggest the preference is a strong one. ${ }^{4}$ That "strong" preference has weakened over time as exceptions to the warrant preference have been created or expanded. 5

Procuring a search warrant often may not be necessary, but it nevertheless is advantageous. The predetermination of probable cause does not provide a perfect shield to subsequent defense attacks on the admissibility of items seized in a search, but it certainly strengthens the prosecution's position. For example, the "good-faith exception" to the exclusionary rule, potentially available in cases in which a warrant was obtained, does not apply at all to warrantless searches. ${ }^{6}$ Quite apart from any legal benefit that may derive from search by warrant, substantial deference to the determination of an issuing magistrate can be expected by trial and appellate judges reviewing the warrant's validity.

Choosing whether to obtain a warrant is not an either/or decision. Evidence seized in a search authorized by a warrant that is later invalidated may be admitted notwithstanding the warrant's defect if the seizure was justified by a warrant exception. This is true even if the officer was unaware of the existence of the exception at the time of the search, or mistakenly believed the exception did not apply. ${ }^{7}$

It would seem, then, that except in emergency situations, acquiring a search warrant always would be preferable. Other than inconvenience and the expenditure of time, it is difficult to imagine any disadvantage in relying on a search warrant. Those factors may loom large in an investigator's thinking, however, if the evidence to be seized is ephemeral or the harm that may

\footnotetext{
${ }^{4}$ Texas v. Brown, 460 US 730 (1983).

${ }^{5}$ See id. at 735-36 (listing cases that have set forth varying exceptions to the warrant requirement).

${ }^{6}$ United States v. Leon, 468 US 897 (1984).

${ }^{7}$ See id. at 919-20.
} 
be done to a potential victim is substantial. Even if there is no particular reason to think the evidence will be moved, sold, consumed, hidden, or otherwise made unavailable in the time necessary to procure a warrant, the mere existence of those possibilities pushes against the impetus to seek a warrant.

From the perspective of law enforcement, the ideal solution in such cases would be a procedure that permits issuance of a search warrant before probable cause exists to believe the contraband or evidentiary items are present. Such a warrant then could be executed almost immediately once reason exists to believe the items sought have arrived at the scene of the authorized search. That is exactly what happened in U.S. v. Grubbs. ${ }^{8}$

\section{Issuance of a Conditional Search Warrant Does Not Violate the Fourth Amendment}

The Postal Inspection Service was in the business of offering child pornography to Internet shoppers. ${ }^{9}$ Jeffrey Grubbs ordered a videotape from the undercover postal inspector operating the website and, conveniently, agents of the Postal Inspection Service (the "Service") were able to set up a "controlled delivery" of the goods to Mr. Grubbs' home. ${ }^{10}$ Since the Service knew exactly what was going to be delivered, and where and when it was going to be delivered, an application for a search warrant was prepared and presented to a magistrate for approval. $^{11}$

The affidavit supporting the warrant application included a recitation of the probable cause facts, and included a statement that:

\footnotetext{
${ }^{8}$ United States v. Grubbs, 547 U.S. 90 (2006).

${ }^{9}$ See id. at 92.

${ }^{10}$ See id.

${ }^{11}$ See id.
} 
Execution of this search warrant will not occur unless and until the parcel has been received by a person(s) and has been physically taken into the residence.... At that time, and not before, this search warrant will be executed by me and other United States Postal inspectors, with appropriate assistance from other law enforcement officers in accordance with this warrant's command. ${ }^{12}$

The warrant issued and was executed two days later, after the package containing the videotape provided by the Service was delivered to the Grubbs' residence. ${ }^{13}$

As expected, the evidence that had been delivered quite helpfully by the Service was found during execution of the search warrant, and Grubbs was arrested. ${ }^{14}$ Subsequently, the accused moved to suppress the incriminating videotape, claiming that its seizure was pursuant to an invalid warrant. ${ }^{15}$ Failing to describe the "triggering condition" ${ }^{16}$ in the warrant (receiving the contraband and taking it into the home) was, according to Grubbs, a fatal defect because the affidavit that did include the triggering condition was not attached to the warrant or given to Grubbs at the time of the search. ${ }^{17}$ The District Court rejected this argument but the Ninth Circuit adopted it, requiring the condition precedent to be set out either on the face of the warrant or in an affidavit "presented to the person whose property is being searched." 18

\footnotetext{
${ }^{12}$ See id.

${ }^{13}$ See id. at 93. Grubbs' wife signed for the package and took it into the home. See id.

${ }^{14}$ See id.

${ }^{15}$ See id. Presumably, there was no claim by the Government of consent to search the home or the existence of any other exception to the warrant requirement. Grubbs had been detained as he left his house shortly after the package was delivered and before the warrant was executed. See id.

${ }^{16}$ Satisfying a "triggering condition" - a condition precedent - effectively marks the establishment of the final probable cause requisite justifying the search. In other words, the "warrant" is no more than a piece of paper without legal force until the triggering condition is met. At that point, the paper is transformed in a valid court order to search.

${ }^{17}$ See id.

${ }^{18}$ See id. at 93-94.
} 
Writing for the majority in the Supreme Court, Justice Scalia first tackled the question of whether a so-called "anticipatory" search warrant violates the Fourth Amendment's probable cause requirement. ${ }^{19}$ If probable cause exists to believe contraband is present on premises at the time a warrant issues, it is "anticipatory" only in the sense that the issuing magistrate believes it likely the evidence still will be present when the warrant is executed, but the warrant is not considered anticipatory in a way that prevents its issuance or execution. Justice Scalia explained that:

Because the probable-cause requirement looks to whether evidence will be found when the search is conducted, all warrants are, in a sense, "anticipatory." In the typical case where the police seek permission to search a house for an item they believe is already located there, the magistrate's determination that there is probable cause for the search amounts to a prediction that the item will still be there when the warrant is executed. ${ }^{20}$

Consequently, it makes no difference to validity that the item expected to be found on the premises is known not to be there at the time of the issuance of the warrant, as long as probable cause exists to believe it will be on the premises at the time the warrant is executed. ${ }^{21}$

Anticipatory warrants may be "no different in principle from ordinary warrants," 22 but they are different in one important practical way. Warrants usually do not contain a condition precedent. For ones that do, it is necessary to establish not only that probable cause exists at the

\footnotetext{
${ }^{19}$ See id. at $94-95$.

${ }^{20}$ Id. at 95.

${ }^{21}$ See id. at 96.

${ }^{22}$ Id.
} 
time of issuance to believe that the item to be seized eventually will be found on the premises, but also that probable cause exists to believe the triggering condition actually will occur. ${ }^{23}$

Viewed in light of practice, however, this "additional" requirement adds little or nothing to the distinction between ordinary warrants and anticipatory ones. Grubbs provides an example typical of the cases in which an anticipatory warrant might be used. The Postal Inspection Service could say with complete confidence that child pornography would be found in the Grubbs' home in the future because the Service was going to deliver it there. ${ }^{24}$ Indeed, the magistrate issuing the warrant in this case could inspect the child pornography to determine its illegal nature even before it was delivered.

Not all anticipatory warrants involve contraband controlled by law enforcement, of course. The police may receive reliable information that an illegal item will be delivered by a third party in the near future to a suspect. Unlike Grubbs, the delivery is not one controlled by law enforcement. Even so, probable cause to believe the contraband will be delivered to the site

\footnotetext{
${ }^{23}$ See id. at 96-97. Justice Scalia spelled out this requirement in his opinion for the Grubbs majority: ...[F]or a conditioned anticipatory warrant to comply with the Fourth Amendment's requirement of probable cause, two prerequisites of probability must be satisfied. It must be true not only that if the triggering condition occurs "there is a fair probability that contraband or evidence of a crime will be found in a particular place," but also that there is probable cause to believe the triggering condition will occur. The supporting affidavit must provide the magistrate with sufficient information to evaluate both aspects of the probable-cause determination.

Id.

${ }^{24}$ The reported cases in which anticipatory warrants have been used most often involve child pornography or, if some other form of contraband, like drugs, one that is controlled by a law enforcement agent. The reported cases in which anticipatory warrants have been used most often involve child pornography or, if some other form of contraband, like drugs, one that is controlled by a law enforcement agent. See, e.g., United States v. Goff, 681 F.2d 1238 (9th Cir. 1982) (upholding a search warrant issued for a person suspected of interstate transportation of cocaine before he actually arrived in the state); United States v. Wylie, 919 F.2d 969 (5th Cir. 1990) (approving the use of anticipatory search warrant in a case involving a controlled delivery of cocaine); United States v. Hale, 784 F.2d 1465 (9th Cir.) (ruling in favor of a search warrant based on a controlled delivery of child pornography, stating that prior issuance of a search warrant is permissible based on the fact that the evidence was on a sure course to its destination); United States v. Goodwin, 854 F.2d 33 (4th Cir. 1988) (agreeing with the test initially proposed by the United States $v$. Hale that an anticipatory warrant, in this case involving a controlled delivery of child pornography through the United States mail, is permissible "where the contraband to be seized is on a sure course to its destination").
} 
necessarily involves evidence - and probably enough evidence to establish probable cause - that the delivery actually will occur. However limited the value of the requirement of probable cause that the condition precedent will be met in the future, it might be seen at least as reinforcing the Court's message to law enforcement that an anticipatory warrant is not an invitation to search prematurely.

Premature search was at the heart of Grubbs' argument that the triggering condition be spelled out in the warrant, or in the affidavit that is then attached to the warrant, in order to give the executing officer notice that the warrant's validity depends upon the condition having been met at the time of execution. This argument was met by the Court's majority noting only that, "the Fourth Amendment does not require that the triggering condition for an anticipatory search warrant be set forth in the warrant itself.",25

Undeniably, the Fourth Amendment contains no textual reference to a "triggering condition," much less an explicit command that such a condition be communicated in a warrant to the executing officer. ${ }^{26}$ The Court nevertheless could have read into the Amendment's reasonableness requirement the need to specify a "starting point" for the execution of the warrant. Justice Souter, author of the concurring opinion in Grubbs, pointed out that,

The notation of a starting date was an established feature even of the objectionable $18^{\text {th }}$-century writs of assistance. And it is fair to say that the very word "warrant" in the Fourth Amendment means a statement of authority that sets

\footnotetext{
${ }^{25} 547$ U.S. 90, 99. Interestingly, the absence of explicit textual support has not stopped the Court from finding an exclusionary sanction implicit in the Fourth Amendment

${ }^{26}$ See id. at 98 . Even the basis for probable cause need not be described on the face of the warrant. Id. "Much less does [the Fourth Amendment] require description of a triggering condition." Id. Of course, the Fourth Amendment also does not explicitly create an exclusionary sanction for violations, and the Fifth Amendment says nothing about prophylactic warnings preceding custodial interrogation.
} 
out the time at which (or, in the case of anticipatory warrants, the condition on which) the authorization begins. ${ }^{27}$

For the majority in Grubbs, requiring the disclosure of the triggering condition on the face of the warrant was not necessary to inform the resident of the limits of police authority under the warrant because neither the Fourth Amendment nor the Federal Rules of Criminal Procedure requires the warrant to be presented to the property owner. ${ }^{28}$ The suggestion by the Ninth Circuit that such a requirement would provide the property owner an opportunity to determine whether the executing officer exceeded his authority ${ }^{29}$ was rejected by Justice Scalia, who observed that the proper safeguard against police officers acting without proper authority is the "deliberate, impartial judgment of a judicial officer." 30 This judicial officer presumably is the magistrate who issues the anticipatory warrant and conditions execution of the warrant on the existence of the triggering condition.

It is unclear how the issuing magistrate can prevent improper execution of the search warrant he or she issues, other than by including on the warrant's face an explicit command to withhold execution until the condition precedent is satisfied. In the event the unaware executing officer acts prematurely, the Grubbs majority suggested off-handedly that the remedies might include suppression of "evidence improperly obtained." 31 But if the opinion in Hudson v Michigan, ${ }^{32}$ a case decided the same year as Grubbs and rejecting the exclusionary remedy for violations of the knock-and-announce rule - another form of execution violation - is any guide,

\footnotetext{
${ }^{27} 547$ U.S. 90 at 100 (Souter, J., concurring). the warrant. See 547 U.S. at 101.

${ }^{29}$ See United States v. Grubbs, 377 F.3d 1072, 1079 ( $9^{\text {th }}$ Cir. 2004).

${ }^{30}$ See United States v. Grubbs, 547 U.S. 90, 99 (2006).

${ }^{31}$ See id. at 99.

${ }^{32}$ See 547 U.S. 586 (2006).
}

${ }^{28}$ See 547 U.S. 90 at 99, citing, Groh v. Ramirez, 540 U.S. 551, 562, n. 5 (2004). The concurring justices countered this observation by noting that the issue remains undecided rather than decided against requiring production of 
the unhappy homeowner whose residence is searched before the triggering condition is met may be left to the unsatisfactory and incomplete vehicles of civil damage litigation against the executing officer ${ }^{33}$ or perhaps departmental disciplinary measures.

As noted by the concurring justices in Grubbs, an anticipatory warrant might not be executed by the officer who obtained it. ${ }^{34}$ In that case, and unless the triggering condition appears on the face of the warrant, the officer would execute the search without any reason to believe that it may not yet be valid. Nor would the homeowner realize until after the fact of the search that the evidence sought by the searching officer is not on the premises. While there is almost no reason to think that an officer with a warrant in hand, faced by a reluctant homeowner claiming that the evidence sought is not inside, would retreat empty-handed on an unverified challenge, ${ }^{35}$ the responsible officer intent on ensuring the validity of the warrant to be executed

\footnotetext{
${ }^{33}$ See 547 U.S. 90 at 99. In Grubbs, Justice Scalia refers to "a cause of action for damages" as a possible remedy for a premature search. Id. Relying on civil damages as a remedy has been criticized by members of the Court and commentators. 547 U.S. 586, 611 (2006) (Breyer, J., dissenting) (Argues that the small number of civil suits only supports the idea that civil suits do not deter violations because violations produce nothing "more than nominal injury"); Richard Emery and Ilann Margalit Maazel, Why Civil Rights Lawsuits Do Not Deter Police Misconduct: The Conundrum of Indemnification and A Proposed Solution, 28 FORDHAM URB. L.J. 587, 590 (2000) (Stating that civil litigation is an ineffective way to punish police misconduct or deter future misconduct because police rarely pay anything out of their own pockets to settle civil lawsuits. Police officers are often not even aware whether the cases settle at all, let alone for how much); L. Timothy Perrin, H. Mitchell Caldwell, Carol A. Chase, \& Ronald W. Fagan, If It's Broken, Fix It: Moving Beyond the Exclusionary Rule: A New and Extensive Empirical Study of the Exclusionary Rule and A Call for A Civil Administrative Remedy to Partially Replace the Rule, 83 IOWA L. REV. 669 (1998) (discussing studies performed regarding existing civil remedies, including litigation and damages, and finding that these remedies cannot and do not effectively deter police misconduct); L. Timothy Perrin, H. Mitchell Caldwell, and \& Carol A. Chase, It Is Broken: Breaking the Inertia of the Exclusionary Rule, 26 PEPP. L. REv. 971 (1999) (mounting evidence exists that shows the exclusionary rule and the civil litigation process fail in their essential function but continue to survive because of the perceived absence of any viable alternatives).

${ }^{34}$ See 547 U.S. 90 at 100-01.

${ }^{35}$ This "argument at the threshold" that the Grubbs majority seems to be imagining does not really represent the purpose of including the triggering condition in the warrant. The Court is correct, of course, in thinking that such an encounter would be unproductive, and therefore should not be encouraged by giving the homeowner grounds for arguing with the executing officer. Instead, the purpose of such a requirement is to alert the executing officer that the warrant may not be valid. In other words, including the triggering condition on the face of the warrant could prevent the violation of Fourth Amendment rights. Naming the triggering condition seems a small burden to bear in order to protect against an inadvertent unlawful intrusion.
} 
would at least be put on notice that he or she is about to act on uncertain authorization. Justice Souter's concurring opinion concludes by observing that in such a case,

If the police were then to enter anyway without a reasonable (albeit incorrect) justification, the search would certainly be open to serious challenge as unreasonable within the meaning of the Fourth Amendment. ${ }^{36}$

In short, under Grubbs the officer who is given an anticipatory warrant to execute may not know that the warrant is anticipatory, or what the triggering condition is, or whether the triggering condition has been met. And the homeowner whose residence is about to be searched need not be given a chance even to inform the officer of any shortcoming prior to execution.

\section{The Short and Uncertain Life of Anticipatory Search Warrants in Texas}

The glory and the danger of federalism is that a state's values may be expressed through its own laws. Those values are not defined entirely by a national compact. If the state believes its citizens are ill-protected by the rights guaranteed in the United States Constitution, it may afford its citizens additional protections. Accordingly, Texas procedural law in numerous ways limits the authority of law enforcement, ways that exceed the reach of the Bill of Rights to the federal constitution. ${ }^{37}$ Texas also is free to provide its citizens less protection, effectively forcing Texans to rely on federal constitutional safeguards. ${ }^{38}$

As a consequence of the substantive overlap in federal and state criminal statutes, many prosecutions may be initiated in either system. The possession or distribution of illegal drugs,

\footnotetext{
${ }^{36}$ See 547 U.S. at 101-02 (Souter, J., concurring).

${ }^{37}$ See Hulit v. State, 982 S.W.2d 431, 436 (Tex. Crim. App. 1998).

${ }^{38}$ See Heitman v. State, 815 S.W.2d 681 (Tex. Crim. App. 1991).
} 
for example, violates both Texas and federal law. ${ }^{39}$ An offender apprehended by state law enforcement officers may be prosecuted in federal court, and those arrested by federal officers might be charged in state court with violating the Texas Penal Code. Determining which system will handle the matter is usually accomplished according to local custom rather than by formulaic prescription. This sort of passing-of-cases simultaneously has produced opportunities for Texas courts to consider the validity of anticipatory warrants, and prevented those same courts from settling how such warrants fare under Texas law.

Fourteen years before U.S. v. Grubbs was decided, a Texas court decided what would become the most important anticipatory warrant case in the state so far. ${ }^{40}$ This time, although the defendant was involved with illegal videotapes and publications as investigators had suspected, ${ }^{41}$ he was actually charged with possession of cocaine discovered during a search of his residence, a search conducted pursuant to an anticipatory warrant. ${ }^{42}$

A federal postal inspector corresponded with the defendant and intended to deliver contraband to him while disguised as a mail carrier. ${ }^{43}$ Before carrying out this delivery, the inspector obtained a warrant based on his belief that child pornography and other evidence would be found on the premises. ${ }^{44}$ It was during the execution of this warrant following delivery of the

\footnotetext{
${ }^{39}$ Tex. Health \& Safety Code Ann. § 481.112(a) (“Except as authorized by this chapter, a person commits an offense if the person knowingly manufactures, delivers, or possesses with intent to deliver a controlled substance..."); 21 U.S.C. §841(a) (Except as authorized by this title, it shall be unlawful for any person knowingly or intentionally-(1) to manufacture, distribute, or dispense, or possess with intent to manufacture, distribute, or dispense, a controlled substance; or (2) to create, distribute, or dispense, or possess with intent to distribute or dispense, a counterfeit substance).

${ }^{40}$ See State v. Toone, 823 S.W.2d 744 (Tex. App. - Houston 1992, pet. granted).

${ }^{41}$ See id. at 745.

${ }^{42}$ See id.

${ }^{43}$ See id.

${ }^{44}$ See id.
} 
package that the agent found cocaine in a jewelry box. ${ }^{45}$ Mr. Toone, the defendant, was charged in state court with possessing cocaine, and in federal court for the obscenity charge. ${ }^{46}$

The defense moved to suppress the cocaine, in part on the ground that it violated the language of article 18.01(b) of the Texas Code of Criminal Procedure, which provides that:

No search warrant shall issue for any purpose in this state unless sufficient facts are first presented to satisfy the issuing magistrate that probable cause does in fact exist for its issuance. A sworn affidavit setting forth substantial facts establishing probable cause shall be filed in every instance in which a search warrant is requested. $^{47}$

Subsection (c) of article 18.01, also cited by the defendant, requires probable cause to believe "that the property or items constituting evidence to be searched for or seized are located at or on the particular person, place, or thing to be searched."48

Toone contended that no offense had been committed at the time the warrant issued because no contraband had yet been delivered by the government agent to the residence. ${ }^{49}$ In effect, probable cause could not establish that the "items constituting evidence" were "located at or on the ... place ... to be searched" because the inspector and magistrate were aware when the

\footnotetext{
${ }^{45}$ See id. It is unclear from the opinion why the searching officer opened the jewelry box. Unless the box was unusually large, or the contraband materials were delivered in a very compact form, it seems a challenge might have been made to the scope of the search.

${ }^{46}$ See id.

${ }^{47}$ TEX. CRIM. PROC. CODE ANN. Art. 18.01(b).

${ }^{48}$ TEX. CRIM. PROC. CODE ANN. Art. 18.02(c).

${ }^{49}$ See 823 S.W.2d at 745.
} 
warrant affidavit was presented for review that the obscene material had not been delivered to Mr. Toone. ${ }^{50}$

After noting the opinions of other state and federal courts that anticipatory search warrants are constitutional, the court of appeals turned to Toone's argument. It concluded that the warrant was "valid." 51 This general finding seems to have been in response to the defendant's contention that article 18.01(b) prohibited the issuance of such warrants. The court did not address, however, whether the language of article 18.01(c) prohibits the issuance of an anticipatory warrant. ${ }^{52}$ The court avoided that decision by employing the "reverse silver-platter doctrine." 53

The silver-platter doctrine harkens back to the time when evidence seized pursuant to a state warrant would be handed to federal authorities on a "silver platter" for use in a federal prosecution. $^{54}$ This procedure avoided the application of stricter federal procedural law since the evidence, validly obtained under state law, was not obtained unlawfully under a federal rule. ${ }^{55}$ Federalism proved its utility as more than a structural concept of constitutional law, but in a manner that the Founders could not have foreseen.

In subsequent years, due to procedural and substantive developments in states and to the changing composition of the Supreme Court, state law often was more protective of individual rights than the broad and often vague prescriptions of the Bill of Rights. If state agents could

\footnotetext{
${ }^{50}$ See id. (defendant "contended that probable cause did not exist at the time the warrant issued because the contraband was no then on the premises").

${ }^{51}$ See id. at 746.

${ }^{52}$ See id.

${ }^{53}$ See id. at $747-48$.

${ }^{54}$ See id. at 748 citing Lustig v. United States, 338 U.S. 74, 79 (1949) ("evidence independently obtained by state officials in compliance with state law, but in violation of federal law, could be handed over on a "silver platter" to federal agents for use in a federal criminal trial").

${ }^{55}$ See id.
} 
pass the platter to their federal counterparts, that platter could as easily be handed back to the states when it proved expedient.

Federal agents are not bound by the limitations of the Texas Constitution, according to the Texas appellate court. ${ }^{56}$ As long as a "state official or person acting under color of state law" did not violate Texas law, Mr. Toone's constitutional rights remained intact. ${ }^{57}$ This holding was tantamount to saying, "Only Texans acting as Texans can violate the Texas Constitution." The federal agents in this case ${ }^{58}$ were seemingly legally incapable of violating state procedural law while serving in their capacity as officers of a "foreign" sovereign. Since they did not (could not) contravene Texas law, the Toone court reasoned, the evidence they found was admissible in a state court. Had they violated the U.S. Constitution, the Fourth Amendment and federal exclusionary rule - or even the Texas exclusionary rule ${ }^{59}$ - could have been invoked to remedy the breach.

There was a second verse to this Toone. ${ }^{60}$ Without expressing an opinion on the virtues of the "reverse silver-platter doctrine" used in the court of appeals, the Texas Court of Criminal Appeals reached the same result by a different route when it reviewed the lower court's holding. ${ }^{61}$ Its analysis began with the Texas exclusionary rule codified in article 38.23 of the Texas Code of Criminal Procedure. ${ }^{62}$ That rule specifies that evidence may not be admitted in a criminal trial if it is "obtained by an officer or other person in violation of any provisions of the

\footnotetext{
${ }^{56}$ See id.

${ }^{57}$ See id.

58 The federal agents in Toone apparently lived and worked in Texas at the time this warrant was obtained and executed. They assumed the status of "others" not subject to the limitations of Texas law because of their status when the search was conducted.

${ }^{59}$ See TEX. CODE CRIM. PROC. ANN. Art. 38.23.

${ }^{60}$ See State v. Toone, 872 S.W.2d 750 (Tex. Crim. App. 1994).

${ }^{61}$ See id. at 751.

${ }^{62}$ See TEX. CODE CRIM. PROC. ANN. Art. 38.23(a).
} 
Constitution or laws of the State of Texas, or of the Constitution or laws of the United States of America."

The Court reasoned that article 18.01 of the Texas code by its terms does not apply to federal search warrants. ${ }^{64}$ The warrant in Toone's case was issued by a federal magistrate and directed to a federal agent. Consequently, it was not a "search warrant" within the meaning of article $18.01,{ }^{65}$ despite clearly being a search warrant under federal law. The Texas exclusionary rule never came into play, according to the Court, because article 18.01 could not have been violated.

What was not said in Toone is more important than the Court's actual holding. Toone says nothing about whether a state anticipatory warrant is valid under article $18.01 .^{66}$ In fact, because the Texas Court of Criminal Appeals decided to base its holding entirely on the inapplicability of article 18.01, the lower court of appeals opinion upholding the validity of anticipatory warrants under that same article was stripped of any effect. Similarly, the "reverse silver-platter" doctrine was neither adopted nor disavowed by the high court's decision. Finally, the Court determined that Toone had failed to preserve any claim he might have hoped to make that the Texas Constitution prohibits anticipatory warrants notwithstanding their validity for Fourth Amendment purposes. ${ }^{67}$

\footnotetext{
${ }^{63}$ See TEX. CODE CRIM. PROC. ANN. Art. 38.23(a).

${ }^{64}$ See 872 S.W.2d 750, 752 (Tex. Crim. App. 1994).

${ }^{65}$ See id.

${ }^{66}$ The Court expressly notes that its holding does not "reflect upon the validity of an anticipatory search warrant which is otherwise governed by article 18.01. See id.

${ }^{67}$ See id. at note 4 .
} 
The upshot of the Court's decision in Toone was recognition of the validity in federal law of a federal anticipatory search warrant. This ruling, now confirmed in its limited reach by Grubbs, says nothing about whether anticipatory warrants are allowed by Texas law.

Five years after Toone was decided, a Texas court of appeals confronted the same issues and, predictably, reached the result dictated by Toone. ${ }^{68}$ A federal agent in Houston was contacted by a customs officer in Miami, Florida, regarding a suspicious FedEx package addressed to a Texas man. ${ }^{69}$ An x-ray of the package, which contained a bread maker, revealed objects inside the appliance that appeared not to belong there. ${ }^{70}$ At the instruction of the Houston agent, the package was sent to him, opened and inspected. ${ }^{71}$ Inside, the agent discovered two bags of cocaine. ${ }^{72}$

A federal anticipatory search warrant was obtained by the Houston federal agent for the apartment to which the package was addressed. ${ }^{73}$ With the aid of the local police department, the package was delivered to the addressee, who identified himself and signed a receipt for its delivery. ${ }^{74}$ A device had been placed inside the package to signal waiting federal officers when it was opened, but after two hours without a signal, they entered the residence. ${ }^{75}$ Inside, they found the unopened box, along with numerous other items associated with the shipping of drugs,

\footnotetext{
${ }^{68}$ See Mahmoudi v. State, 999 S.W.2d 69 (Tex. App. - Houston 1999, pet. ref'd).

${ }^{69}$ See id. at 71.

${ }^{70}$ See id.

${ }^{71}$ See id.

${ }^{72}$ See id.

${ }^{73}$ See id.

${ }^{74}$ See id.

${ }^{75}$ See id.
} 
including records of phone calls and money transfers, and visa applications to Peru, the point of origin for the bread maker. ${ }^{76}$

As in Toone, the defendant Mahmoudi was prosecuted in state court. ${ }^{77}$ His suppression motion was denied; he was tried by a jury, convicted, and sentenced to a lengthy term in prison. ${ }^{78}$ On appeal, he contended that the anticipatory warrant violated article 18.01 of the Texas Code of Criminal Procedure. ${ }^{79}$ Specifically, he cited article 18.01(c)(3) of that code, a provision that requires search warrants be supported by affidavits establishing probable cause to believe evidentiary items be "located at ... the place ... to be searched." $" 80$ While the affidavit used to procure the warrant for Mahmoudi's apartment made clear that the contraband was not yet on the premises, the court of appeals summarily dismissed appellant's claim on the basis of the holding in Toone. ${ }^{81}$ In dicta, the court expressly held, however, that, "The appellant is correct in his assertion that the federal search warrant did not meet the requirements of article 18.01."82 His contention just did not matter because this was a federal warrant directed to a federal agent.

Mahmoudi also argued that the records and papers taken during the search of his apartment should not have been seized because of a prohibition stated in article 18.02 of the code. ${ }^{83}$ That statute excludes "personal writings" from the reach of warrants issued for items of evidence. $^{84}$ Because some of the records seized by officers during their execution of the warrant

\footnotetext{
${ }^{76}$ See id.

77 The opinion of the court of appeals attributes this choice of jurisdiction to the quantity of cocaine discovered. See 999 S.W.2d 69, 71. Apparently, it was a relatively small amount and prosecution in state court was seen as advantageous.

${ }^{78}$ See 999 S.W.2d at 69. Mahmoudi received a sentence of eighteen years and fine of $\$ 60,000$.

${ }^{79}$ See TEX. CODE CRIM. PROC. ANN. Art. 18.01.

${ }^{80}$ See 999 S.W.2d at 71-72; TEX. CODE CRIM. PROC. ANN. Art. 18.01(c)(3).

${ }^{81}$ See 999 S.W.2d at 72.

${ }^{82}$ See id.

${ }^{83}$ See id.; TEX. CODE CRIM. PROC. ANN. Art. 18.02(10) (Vernon Supp. 1998).

${ }^{84}$ See id.
} 
were, in the view of the appellant, "personal writings," they were beyond the scope of the warrant's authority. ${ }^{85}$ Again, the court of appeals overruled the point of error on the ground that state law simply did not apply to this valid federal warrant. ${ }^{86}$

Apart from a sufficiency of the evidence argument, Mahmoudi's only other objection to the admissibility of the evidence was that no probable cause existed to believe evidentiary items other than the cocaine in the package would be found in his residence. ${ }^{87}$ From the totality of circumstances, the appellate court concluded that it was reasonable for the magistrate to infer the probability of the existence of such items on the premises. ${ }^{88}$ Mahmoudi was shown to be a "drug smuggler" and the federal agent who applied for the warrant swore that such evidentiary items would likely be found in the home of a smuggler. ${ }^{89}$

\section{Anticipating the Future of the Texas Anticipatory Warrant}

Magistrates in Texas are issuing anticipatory search warrants in purely state cases. ${ }^{90}$ To date, no published opinion validates this practice, and the criminal procedure code is silent on the subject. ${ }^{91}$ No court has held that the Texas Constitution permits issuance of an anticipatory warrant. In other words, the use of these warrants may or may not be prohibited, or restricted in

\footnotetext{
${ }^{85}$ See id.

${ }^{86}$ See id.

${ }^{87}$ See id. at 72 .

${ }^{88}$ See id. at 73 .

${ }^{89}$ See id.

${ }^{90}$ In 2010 and 2011, I taught classes on this subject to municipal court judges from all over Texas in a training program offered by the Texas Municipal Courts Education Center. When asked whether any of those attending the classes had issued anticipatory warrants, several judges in each class responded that they had issued such warrants and, in some cases, had been doing so for several years.

${ }^{91}$ The Texas Code of Criminal Procedure addresses search warrants generally, but contains no provision specifically addressing anticipatory warrants. Other, general statutory language may apply to the practice, as discussed infra.
} 
some way. Despite the fact that this process has been used in Texas for a number of years mostly by federal warrant - it is unknown whether, or how, state law allows the practice. ${ }^{92}$

\section{A. Constitutionality}

Neither Toone nor Mahmoudi provided any indication of whether anticipatory warrants might violate Article I, Section 9 of the Texas Constitution. Writing for a unanimous court in Toone, Judge Maloney pointedly expressed no opinion on the question:

We emphasize that our holding in this case does not reflect upon the validity of an anticipatory search warrant under the Texas Constitution, nor does it reflect upon the validity of an anticipatory search warrant which is otherwise governed by article $18.01 .^{93}$

During a period of "new federalism," the Court exercised its authority to construe language in the Texas Constitution very differently than the Supreme Court of the United States had done respecting virtually identical wording of guarantees within the U.S. Constitution. ${ }^{94}$ This period coincided with the Court's decision in Toone, which may explain Judge Maloney's effort to emphasize that the holding should not be taken as any comment on the fate of a challenge made under the Texas Constitution. ${ }^{95}$

\footnotetext{
${ }^{92}$ Grubbs settled the question of whether an anticipatory warrant violates the Fourth Amendment, but of course offers no guidance on its validity under state law.

${ }^{93}$ State v. Toone, 872 S.W.2d 750, 752 (Tex. Crim. App. 1994).

${ }^{94}$ See, e.g., Richardson v. State, 864 S.W.2d 944 (Tex. Crim. App. 1993) (holding that use of a "pen register" is a "search" under Article I, Section 9 of Texas Constitution); Autran v. State, 887 S.W.2d 31 (Tex. Crim. App. 1994) (providing greater protection for privacy rights in vehicle inventories than Fourth Amendment); State v. Ibarra, 953 S.W.2d 242 (Tex. Crim. App. 1997) (clear and convincing evidence required for consent in Texas rather than proof of voluntariness by only preponderance of evidence under Fourth Amendment). See generally, REAMEY \& BUBANY, TEXAS CRIMINAL PROCEDURE 97 , notes $1-2\left(10^{\text {th }}\right.$ ed. 2010).

${ }^{95}$ See supra note 93. The new federalism cases date from the period 1991-1997, beginning with the Court's 1991 decision in Heitman v. State, 815 S.W.2d 681 (Tex. Crim. App. 1991).
} 
This brief flirtation with independence from the influence of the national supreme court's view of the fourth amendment ended rather abruptly in $1998 .{ }^{96}$ In that year, the court of criminal appeals decided Hulit v. State, ${ }^{97}$ a case in which it announced that, just as the Texas Constitution might provide greater protection than analogous provisions in the U.S. Constitution, so it might provide less protection. ${ }^{98}$ Specifically, Hulit held that nothing in the Texas document requires a search or arrest warrant in order for a search to be reasonable, ${ }^{99}$ a position at the time quite inconsistent with the repeated admonitions issued by the Supreme Court that warrantless searches and seizures were per se unreasonable for fourth amendment purposes. ${ }^{100}$ Following Hulit, the spark of independence died, apparently the victim of fear that this "two-way-street" view would prove to be a trap into which unwary appellants would fall. ${ }^{101}$

While Judge Maloney's observation in Toone provides some hope for those wishing to challenge the anticipatory warrant on purely state grounds, that hope is slight, and may prove to be illusory. Toone, for example, cited the Texas Constitution in his brief to the court of criminal appeals but, because he failed to cite authority for a different interpretation, or suggest why it

\footnotetext{
${ }^{96}$ Members of the Texas court probably would differ sharply with this characterization. The end of this short era was signaled by an opinion in which the Court repeatedly asserted that its holding was a reflection of independence rather than its death knell.

${ }^{97} 982$ S.W.2d 431 (Tex. Crim. App. 1998).

${ }^{98}$ See 982 S.W.2d at 437 (Texas constitutional protections may be lesser, the same, or greater than federal constitution).

${ }^{99}$ See 982 S.W.2d at 436.

${ }^{100}$ See, e.g., Katz v. United States, 389 U.S. 347, 357 (1967) (holding that searches, for Fourth Amendment purposes, are per se unreasonable when conducted without prior approval by judge or magistrate, subject only to a few exceptions); Coolidge v. New Hampshire, 403 U.S. 443, 477-78 (1971) (stating that in the absence of exigent circumstances, searches and seizures inside a man's house without warrant are per se unreasonable); Horton v. California, 496 U.S. 128, 143-44 (1990) (Providing that seizures of personal property without a warrant, absent exigent circumstances, are also considered "per se unreasonable"); California v. Acevedo, 500 U.S. 565, 580 (1991) (holding that the Fourth Amendment provides a cardinal rule that searches conducted outside the judicial process are per se unreasonable).

${ }^{101}$ Failure to claim a violation of both the Texas Constitution and the U.S. Constitution could result in the application of an unfavorable standard of review for the appellant.
} 
should be read as providing more protection, the Court concluded that he had "preserved nothing" and treated his "claim" as a non-event. ${ }^{102}$

\section{B. Article 18.01(b)}

Toone did preserve his argument that articles 18.01(b) and (c) of the Texas Code of

Criminal Procedure were violated, and the trial judge agreed, granting his suppression motion. ${ }^{103}$ The court of appeals' analysis of this contention consisted of an observation that no case law in Texas holds the anticipatory warrant invalid, and an inventory of other jurisdictions in which "a majority have concluded that anticipatory warrants are constitutional."104 Presumably, none of these other jurisdictions interpreted procedural provisions that were identical to those in effect in Texas and cited by the appellant. ${ }^{105}$

Article 18.01(b) provides that,

No search warrant shall issue for any purpose in this state unless sufficient facts are first presented to satisfy the issuing magistrate that probable cause does in fact exist for its issuance. A sworn affidavit setting forth substantial facts establishing probable cause shall be filed in every instance in which a search warrant is requested. .... ${ }^{106}$

\footnotetext{
${ }^{102}$ See 872 S.W.2d 750, 751, note 4 (Tex. Crim. App. 1994).

${ }^{103}$ See 823 S.W.2d 744, 745 (Tex. App. - Dallas 1992, pet. granted)

${ }^{104}$ See id. at 746 .

${ }^{105}$ The court of appeals compared "probable cause requirements" to reach its decision. See id. at 746-47. The opinion did not mention any comparison of the actual language of the procedure codes.

${ }^{106}$ TEX. CODE CRIM. PROC. ANN. Art. 18.01(b).
} 
This language suggests, as Toone argued, that at the time the anticipatory warrant issued, ${ }^{107}$ probable cause did not yet exist because the contraband clearly was not present on the premises to be searched. Although the court of appeals failed to address this argument, one can imagine its response had it not been sidetracked by the "reverse silver-platter doctrine."

It is true that in the case of anticipatory warrants, probable cause does not exist to believe contraband or evidence is present when the warrant issues. But the nature of probable cause is probability, not certainty. ${ }^{108}$ In all cases, warrants issue on the prediction, based on reliable information, that evidence probably will be found when the warrant is executed. If it is this probability that "counts," then the anticipatory warrant is no more deficient under the article 18.01(b) standard than any other kind of warrant. The Supreme Court relied on this interpretation of probable cause in Grubbs, ${ }^{109}$ and it seems unlikely that a Texas court would read the probable cause requirement in article 18.01(b) more expansively.

An affidavit establishing sufficient probable cause facts to believe that upon the satisfaction of a triggering condition, contraband or evidence will be present, arguably supports the issuance of a warrant; that is, "probable cause does in fact exist for ... issuance" of a search warrant. Grubbs also requires probable cause to believe that the triggering condition will occur, ${ }^{110}$ but nothing in article 18.01 (b) mirrors this element. The anticipatory warrant either is valid because the triggering condition has been met - the contraband or evidence has been delivered - or it is not valid because the condition remains unsatisfied. In effect, an anticipatory

\footnotetext{
${ }^{107}$ See 823 S.W.2d at 745 (Toone contended that probable cause "did not exist at the time the warrant issued because the contraband was not then on the premises).

108 See, e.g., State v. Jordan, 342 S.W.3d 565 (Tex. Crim. App. 2011) (probable cause based on "fair probability" that contraband or evidence will be found in a particular place when warrant is issued).

${ }^{109}$ See United States v. Grubbs, 547 U.S. 90, 95 (2006) ("Because the probable-cause requirement looks to whether evidence will be found when the search is conducted, all warrants are, in a sense, 'anticipatory.'”).

${ }^{110}$ See id. at 96-97.
} 
warrant has no legal force at all until the condition precedent is met, at which time the warrant springs to life by operation of law. Under either the formulation of Grubbs or the wording of article 18.01(b), the result is the same.

In a way, the probability is even stronger when a magistrate issues an anticipatory warrant than when an ordinary warrant issues. In the latter case, the magistrate makes a calculation that evidence probably will be found on the premises when execution occurs, but with many anticipatory warrants it is virtually certain that the evidence will be present upon execution because the government often will have delivered it to the premises, knowing precisely what it was. When an ordinary warrant issues, the magistrate not only must determine the level of probability that evidence will be found in the place to be searched, but must decide how likely it is that the item being searched for is contraband or evidence. This often is the case with an anticipatory warrant. The magistrate in Grubbs could inspect the obscene material that was to be delivered to the suspect to evaluate whether it satisfied the legal definition of obscenity, a rare opportunity indeed for magistrates or law enforcement officers. Similarly, if drugs are to be delivered, they can be tested and weighed ahead of time, establishing their characteristics with much greater certainty than usually is the case. Of course, not all anticipatory warrants involve delivery by the government, but those that do present special opportunities and advantages. Those that do not are no less reliable as a group than ordinary warrants.

Notwithstanding Justice Scalia's approach to the probable cause question, it may be that a Texas court would read the phrase "does in fact exist" more literally. In its opinion in United States v. Hendricks, ${ }^{111}$ the Ninth Circuit, considering whether probable cause existed for issuance of an anticipatory search warrant, noted that "at the time the warrant issued and, in fact, until the

${ }^{111} 743$ F.2d 653 (9 $9^{\text {th }}$ Cir. 1984). 
[triggering condition was met], there was no certainty that [it would be met]." ${ }^{\prime 12}$ The court continued by acknowledging what it termed the "vice of the prospective search warrant": "By issuing such a warrant, the magistrate abdicates to the DEA agents an important judicial function - the determination that probable cause exists to believe that the objects are currently in the place to be searched."113 Because, at the time the warrant issued in Hendricks, the suspect had not picked up the box containing the contraband, much less taken it to the place for which the warrant issued, the court held that the magistrate lacked probable cause. ${ }^{114}$ This general principle subsequently was applied by the Tenth Circuit in United States v. Rowland. ${ }^{115}$

While this concern might be answered now by the requirement of probable cause to believe the triggering condition will occur, it also is possible that a Texas court, following the suggestion of Judge Cochran in her concurring opinion in Jefferson v. State, ${ }^{116}$ would apply an "eighth-grade grammar" approach to interpretation of Article 18.01(b). The clear language in that statute requires that probable cause "does exist" at the time the warrant is issued, presumably to believe criminal evidence at the time of issuance will be found in the place to be searched, and not merely to believe it may be there at some indefinite time in the future.

Unless Texas courts are persuaded to engage in such a strict and literal reading of Article 18.01(b), anticipatory warrants in a post-Grubbs world do not contravene either that procedural provision or the Fourth Amendment. If probable cause exists to believe that the triggering

\footnotetext{
112 See id. at 654 .

${ }^{113}$ See id. at 655 .

${ }^{114}$ See id.

${ }^{115}$ See 145 F.3d $1194\left(10^{\text {th }}\right.$ Cir. 1998)(probable cause showing insufficient to establish that video tapes were likely to be found at suspect's residence).

${ }^{116}$ See 189 S.W.3d 305, 314 (Tex. Crim. App. 2006) (Cochran, concurring) (urging return to "eighth-grade grammar" to read statutes). The Texas Court of Criminal Appeals subsequently has adopted this approach in statutory interpretation. See, e.g., Jones v. State, 323 S.W.3d 885, 890-91 (Tex. Crim. App. 2010).
} 
condition will occur in the future - even though Texas law has nothing to say about this requirement - Texas courts are likely to follow the lead of the Supreme Court and approve the issuance of anticipatory warrants in at least some cases.

\section{Article 18.01(c)}

If subsection (b) of article 18.01 poses no impediment to use of anticipatory warrants Texas, subsection (c) of the same article presents several grounds for challenge of the process. That provision reads as follows:

(c) A search warrant may not be issued under Article 18.02(10) unless the sworn affidavit required by Subsection (b) sets forth sufficient facts to establish probable cause: (1) that a specific offense has been committed, (2) that the specifically described property or items that are to searched for or seized constitute evidence of that offense or evidence that a particular person committed the offense, and (3) that the property or items constituting evidence to be searched for or seized are located at or on the particular person, place, or thing to be searched. .... ${ }^{117}$

Because this requirement is stated in the conjunctive, all three of the enumerated conditions must be met. But before turning to the application of those conditions to anticipatory warrants, it is necessary to consider the limited reach of article 18.01(c).

\section{1. "Evidentiary" warrants}

117 TEX. CODE CRIM. PROC. ANN. Art. 18.01(c). 
By its terms, article 18.01(c) applies only to search warrants issued "under Article 18.02(10)." 118 That subdivision authorizes a search warrant to issue for "property or items, except the personal writings by the accused, constituting evidence of an offense or constituting evidence tending to show that a particular person committed an offense."119 Taken out of context, this provision seems quite broad. It has been construed, however, to extend only to items of "mere evidence,",120 and not to just any and all kinds of evidence. ${ }^{121}$

Since any item sought pursuant to a search warrant must be believed to have evidentiary value, it is useful to consider what is not included within the phrase "mere evidence." The Texas Court of Criminal Appeals has defined the term as describing "evidence connected with a crime, but does not consist of fruits, instrumentalities, or contraband." ${ }^{\prime 22}$ This interpretation was evident at the time it was adopted by the Court from a careful review of the entire "laundry list" of objects in article 18.02 for which a search warrant may issue. ${ }^{123}$ Since the Court characterized "mere evidence" in this way, the list has expanded to include "persons,", 124 but otherwise remains the same.

An item of mere evidence might include a blood, breath, or hair sample, a business record, articles of clothing, or virtually anything that may point to the guilt or innocence of a

\footnotetext{
${ }^{118}$ See id.

${ }^{119}$ See TEX. CODE CRIM. PROC. ANN. Art. 18.02(10).

${ }^{120}$ The term "mere evidence" has been used to describe seizures authorized by article 18.02(10). See, e.g., Thomas v. State, 352 S.W.3d 95 (Tex. App. - Houston [14 ${ }^{\text {th }}$ Dist.] 2011, no pet.); Carmen v. State, 358 S.W.3d 285 (Tex. App. - Houston [1 ${ }^{\text {st }}$ Dist.] 2011, no pet.); Scott v. State, 868 S.W.2d 430, 432-33 (Tex. App. - Waco 1994, pet. ref'd); Joseph v. State, 807 S.W.2d 303 (Tex. Crim. App. 1991).

${ }^{121}$ See State v. Acosta, 99 S.W.3d 301 (Tex. App. - Corpus Christi 2003, pet. ref'd); Gentry v. State, 640 S.W.2d 899 (Tex. Crim. App. 1982) (blood sample is "item of evidence" covered by subsection (10)).

${ }^{122}$ See Joseph v. State 807 S.W.2d 303, 307 (Tex. Crim. App. 1991); see also Reamey \& Bubany, TEXAS CRIMINAL PROCEDURE $52\left(10^{\text {th }}\right.$ ed. 2010).

${ }^{123}$ See TEX. CODE CRIM. PROC. ANN. Art. 18.02.

124 The addition of "persons" to the list of "things" to be searched for is explained by the decision in Steagald $v$. United States, 451 U.S. 204 (1981) (warrantless entry into residence of third party to execute arrest warrant for fugitive violates Fourth Amendment in absence of consent or exigent circumstances).
} 
suspect. "Fruits" of a crime, on the other hand, are those objects obtained as a result of the criminal activity, like the jewelry taken in a burglary. Similarly, an "instrumentality" of crime is a thing used to commit the offense, perhaps a crowbar or pistol. "Contraband," of course, is anything that is illegal to possess. ${ }^{125}$ Virtually anything of evidentiary value other than fruits, instrumentalities, and contraband qualifies as "mere evidence" and falls within article 18.02(10).

Probably because the scope of an evidentiary search warrant is so broad, not all magistrates are authorized to issue these warrants. The limitation also may be based in part on recognition that items of mere evidence, which are innocent in themselves, may be found on premises controlled by persons not engaged in any criminal activity, and they may not be instantly recognizable as related to criminal activity. Searches for such items may, therefore, be particularly intrusive.

Article $18.01(\mathrm{c})$ requires the issuing magistrate for an evidentiary warrant to be a judge of a municipal court of record or county court who is licensed to practice law, or a judge of a higher level court. ${ }^{126}$ Exceptions are made for counties that do not have attorney-judges in the lower courts, and in certain blood-warrant cases for counties lacking lower level courts of record. ${ }^{127}$

The definition of evidentiary warrants restricts their reach in a way that may not apply to many anticipatory warrant situations. Where the evidence sought to be recovered is child pornography (e.g., Grubbs) or drugs (e.g., Mahmoudi), the anticipatory warrant is not an evidentiary warrant because those items are contraband and authorized by other parts of Article

\footnotetext{
${ }^{125}$ See BLACK'S LEGAL DICTIONARY ( $9^{\text {th }}$ ed. 2009) defining contraband as "goods that are unlawful to import, export, produce, or possess."

${ }^{126}$ See TEX. CODE. CRIM. PROC. ANN. Art. 18.01(c).

${ }^{127}$ See id. at Art. 18.01(i), (j).
} 
18.02. ${ }^{128}$ On the other hand, an anticipatory warrant may be sought for items of mere evidence, in which case the strictures of article 18.01(c) apply.

\section{A different "Toone"}

Toone's argument in the court of appeals was the right argument in the wrong case. Child pornography was sought in the search of Toone's home, and drugs were found. ${ }^{129}$ His state law issue, had it been considered, turned on the validity of anticipatory warrants under article 18.01(b), the provision that applies to all sorts of search warrants, and not to article 18.01(c), which is limited to evidentiary warrants. For reasons previously discussed, there is no reason after Grubbs to think a Texas court categorically would reject anticipatory warrants on the basis of language in article 18.01(b). The rules pertaining to evidentiary warrants, on the other hand, were simply inapplicable to seizure of the items sought in Toone's case. Without resort to Grubbs and silver platters, the result would not have been different in Toone if the warrant had been issued by a Texas judge rather than a federal magistrate.

It should have been different, however, if the anticipatory warrant had been an evidentiary one. Consider the first of the requirements of article 18.01(c): The affidavit for the evidentiary warrant must set forth probable cause "that a specific offense has been committed." ${ }^{130}$ In the event that the missing piece of evidence sought to be discovered by execution of the anticipatory warrant is essential to establish a completed crime, an affidavit alleging that the evidence will be supplied in the future does not suffice to satisfy the

\footnotetext{
${ }^{128}$ See TEX. CODE CRIM. PROC. ANN. Arts. 18.02(6), (8) (authorizes commercial obscenity and other items for which possession is prohibited), 18.02(7) (drugs).

${ }^{129}$ The drugs arguably were discovered in "plain-view" because the officers executing the anticipatory warrant were entitled to search for obscene material in the box where the drugs were found and it was immediately apparent to them that what they discovered was contraband.

${ }^{130}$ See TEX. CODE CRIM. PROC. ANN. Art. 18.01(c) (emphasis added).
} 
requirement. While it is easier to imagine this being the case with contraband, it is conceivable that an item of mere evidence might play the same indispensable role.

Subsection (c) of article 18.01 also presents a second formidable impediment for anticipatory warrants. It provides that the probable cause affidavit establish "that the property or items constituting evidence to be searched for or seized are located at or on the particular person, place, or thing to be seized." ${ }^{\prime 131}$ The very nature of an anticipatory warrant contradicts meeting this requirement. Evidence expected to be found on the premises in the future is not presently located at that place. An anticipatory evidentiary warrant, therefore, cannot issue under Texas law as it now exists.

The state of the anticipatory warrant in Texas might be summarized as follows: An anticipatory warrant properly issued by a federal magistrate is valid in Texas. An anticipatory warrant properly issued in state court for items not controlled by article 18.01(c) of the Texas criminal procedure code - that is, not for items of "mere evidence" - probably would be upheld, although the question has not yet been decided. ${ }^{132}$ An anticipatory warrant issued in state court for items of "mere evidence" probably would not survive textual analysis under article 18.01(c). ${ }^{133}$ These article 18.01 issues have not been addressed by an appellate court in Texas and, lest it be thought that the Texas Court of Criminal Appeals impliedly has blessed the issuance of an anticipatory warrant by a state court, that court stated in Toone that "[its] holding in this case does not reflect upon the validity of an anticipatory search warrant under the Texas

\footnotetext{
${ }^{131}$ See id.

${ }^{132}$ Recall that neither Toone nor Mahmoudi involved state warrants. Both searches were pursuant to federal warrants.

${ }^{133}$ See GEORGE DIX \& JOHN SCHMOLESKY, 40 CRIMINAL PRACTICE AND PROCEDURE Sec. 9:45 (3d ed. 2011) (“the Code may well bar anticipatory warrants for 'mere evidence' but impose no such prohibition upon anticipatory warrants for other items"); Dan Rogers, U.S. Supreme Court Holds Fourth Amendment Permits Anticipatory Search Warrants, 43-JUN HOUS. LAW. 70 (May/June 2006)(Toone expressly left open whether Article 18.01(c) prohibits Texas magistrate from issuing anticipatory search warrant).
} 
Constitution, nor does it reflect upon the validity of an anticipatory search warrant which is otherwise governed by article 18.01."134 If anything, Judge Maloney's disclaimer hints that such arguments are "live" ones, regardless of what the disposition of those arguments eventually might be.

\section{Execution timing problems}

Professors George Dix and John Schmolesky raise a different concern in Texas law about anticipatory warrants. ${ }^{135}$ Ordinarily, when a magistrate issues a search warrant the judge has decided, not only that probable cause exists at the time the warrant is signed, but will continue to exist for as long as it remains valid. ${ }^{136}$ Unless a shorter period of validity is imposed by the issuing magistrate, a search warrant ordinarily remains in force for three days, exclusive of the day of its issuance and the day of its execution. ${ }^{137}$ A longer period is allowed for execution of a warrant authorizing seizure of a sample for DNA testing. ${ }^{138}$ The seizure of data or information from a computer drive, cell phone, or other data storage device also is subject to a special timing rule. $^{139}$

As Dix and Schmolesky correctly note, in the case of an anticipatory warrant the magistrate cannot always determine whether probable cause will continue to exist for the duration of the statutory period allowed for execution. ${ }^{140}$ They conclude that this inability to predict the continuing vitality or duration of probable cause for some indefinite period in the

\footnotetext{
${ }^{134}$ State v. Toone, 872 S.W.2d 750, 752 (Tex. Crim. App. 1994).

${ }^{135}$ See GEORGE DIX \& JOHN SCHMOLESKY, 40 CRIMINAL PRACTICE AND PROCEDURE Sec. 9:45 (3d ed. 2011).

${ }^{136}$ See id.

${ }^{137}$ See TEX. CODE CRIM. PROC. ANN. Art. 18.07(a)(2).

${ }^{138}$ See id. art. 18.07(a)(1) (allowing 15 days for the search and seizure of DNA samples).

${ }^{139}$ See id. art. 18.07(c) (execution of warrant is deemed to have occurred when device is seized rather than when the date actually is examined).

${ }^{140}$ See GEORGE DIX \& JOHN SCHMOLESKY, 40 CRIMINAL PRACTICE AND PROCEDURE Sec. 9:45 (3d ed. 2011).
} 
future, effectively "relieves the issuing magistrate of any responsibility to consider whether the submitted facts might be sufficient to establish that probable cause exists and will continue to exist for a short period but will not continue during the statutory period for executing a warrant." $" 141$

This concern also applies to ordinary search warrants, and explains in part why execution is time-limited. ${ }^{142}$ Not only is evidence, to varying degrees, likely to be consumed, distributed, moved, altered, or otherwise made unavailable over time, but it also may lose its evidentiary significance as time passes. Limiting the execution period to a few days following the probable cause determination lessens the chance that probable cause will dissipate before the search is made.

If a magistrate anticipates that probable cause facts may change quickly, he or she is authorized to shorten the time allowed for execution. ${ }^{143}$ While that alternative may alleviate the concern in case an ordinary warrant is sought, due to the nature of the anticipatory warrant the magistrate may be less able to predict whether or how the strength of the probable cause showing will change after the triggering condition occurs or, if so, how quickly it will do so. ${ }^{144}$ At least, the magistrate who issues an anticipatory warrant should inquire into whether the probable cause facts will remain undiluted during the statutory period allowed for execution, ${ }^{145}$ although no

\footnotetext{
${ }^{141}$ See id.

${ }^{142}$ Arrest warrants, as opposed to search warrants, are not required to be executed within a certain time.

${ }^{143}$ See TEX. CODE CRIM. PROC. ANN. Art. 18.06(a) (warrant "shall be executed within a shorter period if so directed in the warrant $b$ the magistrate").

${ }^{144}$ See GEORGE DIX \& JOHN SCHMOLESKY, 40 CRIMINAL PRACTICE AND PROCEDURE Sec. 9:45 (3d ed. 2011) (noting that "in at least some situations the passage of time can affect the significance of information").

${ }^{145}$ See GEORGE DIX \& JOHN SCHMOLESKY, 40 CRIMINAL PRACTICE AND PROCEDURE Sec. 9:45 (3d ed. 2011).
} 
such requirement currently exists in Texas law. ${ }^{146}$ It is unlikely, after all, that the officer seeking the warrant will propose such a limitation, and she has no statutory duty to do so.

\section{E. Describing the "triggering condition"}

As discussed previously, the Fourth Amendment does not require that the triggering condition for an anticipatory warrant be described on the face of that warrant, or that the affidavit describing the triggering condition be attached to the warrant. ${ }^{147}$ Even the existence of a triggering condition is not required, nor is it necessary to identify the warrant as an "anticipatory warrant." None of this will matter, of course, if the executing officer is the affiant or someone sufficiently involved in the investigation to know that there is a triggering condition, and perhaps to know what it is.

In practice, however, officers sometimes are required to execute search warrants without having the benefit of complete information about the investigation that produced it. An anticipatory warrant is sufficiently rare that an executing officer cannot be presumed to have considered the possibility that a triggering condition has not occurred, or even that one existed. For the reasons previously elaborated, the prospect of an unlawful search pursuant to a "warrant" that has not yet come into force may not be remediable. It is a prospect, though, that usually can be avoided by the simple expedient of doing a bit more than the Fourth Amendment requires.

If the triggering condition is set forth in the warrant, or at least in the attached affidavit, the executing officer would have at hand information that might avert an unlawful search. Even

\footnotetext{
${ }^{146}$ Dix and Schmolesky suggest that a defendant subjected to an anticipatory warrant search "should be able to argue that [the warrant] was executed at a time when the facts failed to show continuing probable cause." See GEORGE DIX \& JOHN SCHMOLESKY, 40 CRIMINAL PRACTICE AND PROCEDURE Sec. 9:45 (3d ed. 2011).

147 See United States v. Grubbs, 547 U.S. 90, 99 (2006); cf. State v. Moran, 791 So.2d 1065, 1071 (Ala. Crim. App. 2001) (holding triggering condition need not be stated on face of anticipatory warrant).
} 
a clear legend appearing on the warrant, alerting the officer that it is not the "ordinary" kind, would improve the chances that a premature search would not occur. While neither of these requirements exists within the reasonableness requirement of the Fourth Amendment, either might be addressed by a state procedure code. In the absence of a statutory directive, the magistrate always is authorized to ensure that the condition precedent is stated clearly on the warrant's face. ${ }^{148}$ That small inconvenience, if it is one, seems a small price to pay for greater security against claims of a Fourth Amendment violation. As the First Circuit Court of Appeals observed regarding anticipatory warrants generally, "magistrates who are asked to issue such warrants must be particularly vigilant in ensuring that the opportunities for exercising unfettered discretion are eliminated." 149

\section{Anticipating and Avoiding Challenges to the Texas Anticipatory Warrant}

The inclusion of mere evidence as the object of a search conducted pursuant to an anticipatory search warrant can be accomplished by modifying the language of Article 18.01(c) or by creating an express exception for such warrants. If Texas is going to use anticipatory warrants routinely, however, a comprehensive statute should be added to chapter 18 of criminal procedure code, creating and defining the requirements and scope of such warrants in the same way that chapter addresses ordinary search warrants.

Such a statute would spell out the constitutionally mandated elements identified in Grubbs, but also would provide guidance on the staleness issue that concerns Dix and Schmolesky, and possibly require inclusion of the triggering condition on the face of the warrant, or at least mandate identifying the warrant as anticipatory. For reasons previously discussed, providing the

\footnotetext{
${ }^{148}$ See State v. Moran, 791 So.2d 1065, 1071 (Ala. Crim. App. 2001) ("it would be preferable for the issuing judge to include the condition precedent in warrant itself").

${ }^{149}$ United States v. Ricciardelli, 998 F.2d 8, 12 (1 ${ }^{\text {st }}$ Cir. 1993).
} 
executing officer more information about the nature and scope of the warrant could prevent searches that only retrospectively will be determined to lack probable cause. Nothing about this additional requirement thwarts the purpose of the anticipatory warrant or unduly burdens law enforcement or magistrates. To the contrary, additional clarity in court orders permitting the invasion of citizens' most private places benefits officers and better protects liberty interests.

Without sufficient guidance from the Texas courts and legislature, officers are faced with two alternatives: rely only on the very general contours found in Grubbs and Article 18.01, or avoid the use of the anticipatory warrant altogether. The former is a relatively safe course of action, assuming Texas constitutional safeguards are held to be the same as those of the Fourth Amendment, and assuming further that the search is not one for items of mere evidence, and that Article 18.01(b) is held not to create an impediment to the use of the anticipatory warrant. The "relative safety" of this course of action clearly also carries downside risk that vital evidence will be lost or harm to important societal interests may occur due to uncertainty about the validity of the search technique, an uncertainty that could be eliminated statutorily.

The alternative - avoiding the use of anticipatory warrants altogether - carries similar costs, but also can carry the benefit of returning the investigator to surer ground. If, for example, no anticipatory warrant is sought, an investigator nevertheless could prepare a warrant affidavit setting out what the officer feels sure will happen (e.g., the package will be delivered). After determining, usually through surveillance or delivery, that the suspect actually has received the contraband, the officer is free to immediately seek an ordinary search warrant ${ }^{150}$ based on what already has happened, rather than what is expected to occur. The obvious disadvantage of this

\footnotetext{
${ }^{150}$ For obvious reasons, this is sometimes referred to as a "stand-by warrant." The affiant "stands by," waiting for the moment probable cause facts exist, and then executes the affidavit.
} 
"old-school" approach is that in the interval following delivery, and before the warrant can be obtained, evidence may be moved, destroyed, modified, or consumed. If this happens, it is a high price to have paid for the uncertainty that easily could have been avoided by statutory guidance.

In spite of any rules defining and limiting anticipatory warrant use in Texas, issues will arise. The particularity requirement, for instance, was addressed superficially in Grubbs by noting that the Fourth Amendment requires particular description only of "the place to be searched" and "the persons or things to be seized." ${ }^{151}$ The Court used this observation only to segue into a discussion of Grubbs's argument that the triggering condition or other "precondition to the valid exercise of executive power" must be "particularly identified" on the face of a warrant. ${ }^{152}$ Nothing in the Constitution, according to the Court, requires preconditions to be set forth because the particularity requirement apparently is limited to the narrow confines of its specific textual command. ${ }^{153}$

A different aspect of particularity may arise, however, one not fully considered in Grubbs. The police in People v. Bui ${ }^{154}$ planted a tracking device in a package they determined contained "ecstasy" tablets. ${ }^{155}$ Because they did not believe the nail salon to which the package was

\footnotetext{
${ }^{151}$ See 547 U.S. at $97-98$.

${ }^{152}$ See id.

${ }^{153}$ See id. The Court responded to Grubbs's contention by observing: That principle is not to be found in the Constitution. The Fourth Amendment does not require that the warrant set forth the magistrate's basis for finding probable cause, even though probable cause is the quintessential "precondition to the valid exercise of executive power." Id. at 98 . Much less does it require description of a triggering condition.

154 People v. Bui, 381 III.App.3d 397, 885 N.E.2d 506 (III. App. 2008).

155 See id. at 511-12.
} 
addressed was its final destination, ${ }^{156}$ an anticipatory warrant was obtained for the premises at "any ... location that the parcel is accepted ...."157 The warrant ultimately was executed at a location to which the package was taken, a location previously unknown to police. ${ }^{158}$

The defendant contended that issuing a warrant with no specific description of the place to be searched violated the Fourth Amendment's particularity requirement. ${ }^{159}$ Because Bui did not preserve this argument by raising it in his motion to suppress, the appellate court considered the issue waived. ${ }^{160}$ The argument, though, seems meritorious and serves both as a reminder of the core particularity requirement reflected in the Grubbs analysis and as an example of the constitutional risks inherent in employing a warrant issued on an incomplete factual basis.

Potential errors of the sort Bui wanted to argue on appeal raise the prospect that "good faith" will play a somewhat expanded role in post hoc review of an anticipatory warrant's validity. Warrant deficiency was the central issue in United States $v$. Turner, ${ }^{161}$ a case in which the defendant complained that probable cause for the anticipatory warrant was lacking in light of the possibility that the triggering condition - actual delivery to the addressee - might not occur if the addressee refused to accept delivery. ${ }^{162}$ The District Court rejected on the facts of the case the claim that probable cause did not support the warrant, but also opined that, even if the defendant

\footnotetext{
${ }^{156}$ The addressee did not reside at the address and no one in the state used the address for driver's license purposes. See id.

${ }^{157}$ See id. at 511.

${ }^{158}$ See id. at 512.

${ }^{159}$ See id. at 514.

${ }^{160}$ See id. at 514-15.

${ }^{161}$ United States v. Turner, 491 F.Supp.2d 556 (E.D. Va. 2007).

${ }^{162}$ See id.
} 
was correct on that point, the good faith exception would have permitted the officers to rely on the anticipatory warrant issued by the magistrate. ${ }^{163}$

The Turner court duly analyzed whether the officers' reliance on the warrant was objectively reasonable, applying guidelines set forth in United States v. Leon. ${ }^{164}$ While this application of good-faith often will resolve claims that probable cause did not support the issuance of an anticipatory warrant, in Texas the result is likely to be quite different.

The Texas exclusionary rule is statutory. ${ }^{165}$ That statute was amended to create a good faith exception for Texas:

(b) It is an exception to the provisions of Subsection (a) of this Article that the evidence was obtained by a law enforcement officer acting in objective and good faith reliance upon a warrant issued by a neutral magistrate based on probable cause. $^{166}$

The exception, however, does not mirror the federal version created in Leon. The Texas Court of Criminal Appeals has held that, based on the plain wording of Article 38.23(b), good faith will not save evidence from exclusion unless the warrant on which the State relies was "based on probable cause."167 Where probable cause was lacking from the face of the warrant affidavit, whether due to insufficient particularity or for other factual inadequacy, the existence of a reasonable good faith mistaken belief that the warrant actually was based on probable cause makes no difference in Texas. Consequently, errors in judgment on the probable cause issue by

\footnotetext{
${ }^{163}$ See id. at 562-62.

164 United States v. Turner, 492 F.Supp.2d 556, 562-63 (E.D. Va. 2007), citing, United States v. Leon, 468 U.S. 897 , 914-15, 923 (1984).

${ }^{165}$ See TEX. CODE CRIM. PROC. ANN. Art. 38.23.

${ }^{166}$ See TEX. CODE CRIM. PROC. ANN. Art. 38.23(b).

${ }^{167}$ See Curry v. State, 808 S.W.2d 481 (Tex. Crim. App. 1991).
} 
magistrates approving anticipatory warrants are not excused, and evidence obtained by executing those warrants will not be admissible.

It would be a mistake to view the dearth of opinions from Texas appellate courts on the issues surrounding anticipatory warrants as an indication either that such warrants are not being issued in Texas, or that Grubbs provides sufficient guidance for their use. As this practice becomes more familiar and those working in the criminal justice system come to appreciate the ways in which anticipatory warrants differ from other warrants, challenges must be expected. Effective and comprehensive statutory guidance on the use of the anticipatory warrant by state law enforcement agencies in state prosecutions is the surest way to provide the certainty law enforcement deserves, as well as providing the protection Texas citizens require. Whether the future of the anticipatory warrant will be shaped by piecemeal and incomplete responses to challenges by defendants, ${ }^{168}$ or instead by thoughtful legislative definition and guidance, for now, Texans are left only anticipating.

${ }^{168}$ An example of a court resorting to alternative solutions in the absence of guidance can be found in Sandoval $v$. State, 1995 WL33620 (Tex. App. - Dallas 1995) (not designated for publication) (court relies on "team approach" to justify warrantless arrest and subsequent search incident to arrest in lieu of anticipatory warrant). 